\title{
Literacies of Civic Engagement: Negotiating Digital, Political and Linguistic Tensions
}

\author{
CASEY BURKHOLDER \\ McGill University \\ DIANE WATT \\ University of Ottawa
}

Introducing the Special Issue

Language and literacy practices are instruments of power and are inherently political. What languages we speak (and where we speak them), how we use literacy, and who we speak to, are issues that are intimately entwined with questions of belonging, identity, status, and citizenship. In the light of current events in Canada, and around the world, negotiating the language of belonging and citizenship are as contested as ever. What is more, ongoing changes in the ways that people make and consume texts remind us of the need to engage with such questions frequently and thoughtfully. Of course literacy refers to much more than just reading written texts. In her keynote address on Literacy and Civic Engagement, Jacqueline Jones Royster quoted Sojourner Truth who responded to a literacy prerequisite for voting rights with the telling, "You know, children, I don't read such small stuff as letters, I read men and nations" (as quoted in Royster, 2007, p. 4). Language, literacy, power, men, and nations are all being taken up in the contributions in this special issue.

Thinking about these issues in the wake of the 2016 US presidential election, multiple examples of the ways in which language and literacy practices across texts and spheres hold important-and sometimes contradictory-meanings have arisen. Take the example of the multiple meanings given to terms like "fake news". Initially, the term "fake news" was used by mainstream media sources to describe content farms that hosted unsourced, unverifiable and fictitious news stories intended to elicit responses and be shared digitally (Marchi, 2012). Later, the term was used by US President Trump in particular, largely on Twitter, to refer to critical media coverage of his presidency, campaign, and the events leading up to it. Looking at the evolution of the term "fake news" and the power this term has been given reminds us that what we communicate, whom we communicate with, and how we are doing this communicating are inherently political.

The spaces where we communicate from and our link to these places are also political — both in the spaces we inhabit and in the digital realm. For example, we are white settlers interested in issues of language, belonging, and civic engagement. I am writing this editorial from unceded Wolastoqiyik and Mi'kmaq territory-Fredericton, New Brunswick-and Diane writes from traditional unceded Algonquin territory in Ottawa, Ontario. What does it mean to write about issues of language, literacy and civic engagement from unceded lands? How might we think about unsettling these issues? The University of New Brunswick’s Elder-in-Residence Imelda Perley, uses digital spaces, such as Twitter to share teachings of the Wolastoq language. On June 5, 2017, for example, Elder Perley tweeted, "Psiw Ntulnapemok-(pss-eow-ndole-nah-beh-mg) all my relations. A term used to honour all of creation, animal, earth, water, winged \& tree clans.” Using 
digital spaces — such as Twitter - to share teachings, ways of knowing, and thinking about language, literacy, power and place reveals the ways in which sharing language and literacy practices on social media are distinct acts of civic engagement.

Building from the 2016 Language and Literacy Researchers of Canada preconference in Calgary, Alberta: Literacies of Civic Engagement: Negotiating Digital, Political, and Linguistic Tensions, this special issue of Language \& Literacy includes new and established language and literacy scholars writing about the intersections between literacies, civic engagement, and communicating across differences, both face-to-face as well as in the digital realm. Together, the authors in the special issue have offered multiple reflections on language, literacies, and civic engagement building from the "exquisite conversations" held at the 2016 Language and Literacy Researchers of Canada preconference.

\section{Overview of the Contributions}

The first article in the special issue is Heather Lotherington's (York University), "Elementary School Language and Literacy Education for Civic Engagement: An Evolving Playbook for Post-modern Times.” Lotherington's piece explores her longitudinal project at Joyce Public School in Toronto (2002-2012), and discusses how language and literacies are constituted, performed and taught within elementary classroom spaces. Lotherington ruminates on the place of language within elementary school projects to foster participatory civic engagement within the classroom.

The second contribution, "The Techno-literacy Practices of Young Children from Diverse Backgrounds” comes from Nicola Friedrich (OISE / University of Toronto), Laura Teichert (University of British Columbia) and Zipporah Devadas (British Columbia School District 35). Through two ethnographic case studies, the article describes the home technoliteracy practices of children from diverse economic and cultural backgrounds.

The third piece, "Using a Graphic Novel Project to Engage Indigenous Youth in Critical Literacies” comes from Alexis Brown (University of Victoria) and Deborah Begoray (University of Victoria). The article describes a graphic novel making project with Indigenous youth at two alternative high schools in British Columbia and explores four principles of critical literacy with these youth: "understanding power", "collaboration using multiple perspectives”, "authentic and multimodal learning”, and "enacting social change and civic engagement”.

In the fourth contribution in the issue, “"Before Occupy Central, I Wasn't Concerned”: Examining Participatory Visual Research for Social Change with Hong Kong-based Filipina Youth” comes from Casey Burkholder (McGill University). Describing a participatory visual research project using cellphilms (cellphone + filmmaking) and collaborative writing with two of her Filipina-Hong Kong participants, Burkholder describes the way that Hong Kong's Occupy Movement encouraged Filipina young women's sense of belonging and civic engagement in the territory.

Finally, Christine Kampen Robinson's (University of Waterloo), "Speaking Menonnite at School: A Narrative Analysis of the Role of Language in Immigrant Educational Experiences" explores the perspective of identity as it is constructed by language through an ethnographic project with Mennonite mothers who have emigrated from Mexico to Canada. This research looks at the worlds of Low German-speaking Mennonite women and the ways in which they speak. 


\section{Acknowledgements}

This Special Issue would not have been possible without the assistance of a number of key people who have helped along the way: Diane Watt (University of Ottawa) who co-edited

the Special Issue, Maureen Kendrick (University of British Columbia), the Language and Literacy Researchers of Canada executive team (with special thanks to Lyndsay Moffatt, University of Prince Edward Island) and Diane Collier (Brock University), and the 2016 Language and Literacy Researchers of Canada pre-Conference participants.

\section{References}

Marchi, R. (2012). With Facebook, blogs, and fake news, teens reject journalistic “objectivity”. Journal of Communication Inquiry, 36(3), 246-262.

Perley, I. [askomiw150]. (2017, Jun 05). Psiw Ntulnapemok-(pss-eow-ndole-nah-behmg) all my relations. A term used to honour all of creation,animal, earth,water, winged \& tree clans [Tweet]. Retrieved from https://twitter.com/askomiw150/status/871852687003930625

Royster, J. (2007, September). Literacy and civic engagement. Keynote address presented at the Civil rights symposium: An interdepartmental and interdisciplinary conversation on civil rights reform, Albuquerque, NM. Retrieved from https://www.unm.edu/ wac/old_site/CurriculumResources/ROYSTER-Keynote\%20Address--2007.pdf. 